\title{
The Effects of Manganese Dopant Content and Calcination Temperature on Properties of Titania-Zirconia Composite
}

\author{
Muhamad Imam Muslim', Rian Kurniawan ${ }^{2}$, Mokhammad Fajar Pradipta ${ }^{1}$, \\ Wega Trisunaryanti ${ }^{1}$, and Akhmad Syoufian ${ }^{1^{*}}$ \\ ${ }^{1}$ Department of Chemistry, Faculty of Mathematics and Natural Sciences, Universitas Gadjah Mada, \\ Sekip Utara, 55281 Yogyakarta, Indonesia \\ ${ }^{2}$ Institute of Chemical Technology, Universität Leipzig, Linnéstr. 3, 04103 Leipzig, Germany
}

\section{* Corresponding author:}

email:akhmadsyoufian@ugm.ac.id

Received: December 5, 2020

Accepted: March 24, 2021

DOI: $10.22146 /$ ijc. 61900

\begin{abstract}
The effects of dopant content and calcination temperature on Mn-doped $\mathrm{TiO}_{2}-\mathrm{ZrO}_{2}$ structure and properties were successfully investigated. Composite of $\mathrm{Mn}$ doped titania-zirconia was synthesized by sol-gel method. Titanium(IV) isopropoxide was used as the precursor of $\mathrm{TiO}_{2}$, while zirconia powder was used as another semiconductor. $\mathrm{MnCl}_{2} \cdot 4 \mathrm{H}_{2} \mathrm{O}$ was used as the source of dopant in this study. Various amounts of manganese were incorporated into $\mathrm{TiO}_{2}-\mathrm{ZrO}_{2}$ and calcination was performed at temperatures of 500, 700 and $900{ }^{\circ} \mathrm{C}$. Synthesized composites were characterized by Fourier-transform infrared spectroscopy (FTIR), specular reflectance UV-Vis spectroscopy (SR UV-Vis), X-ray diffraction method (XRD) and scanning electron microscopy equipped with $X$-ray energy dispersive spectroscopy (SEM-EDX). The results showed that $\mathrm{Mn}$-doped $\mathrm{TiO}_{2}-\mathrm{ZrO}_{2}$ with the lowest bandgap $(2.78 \mathrm{eV})$ was achieved with $5 \%$ of $\mathrm{Mn}$ dopant and calcined at $900{ }^{\circ} \mathrm{C}$, while $\mathrm{Mn}$-doped $\mathrm{TiO}_{2}-\mathrm{ZrO}_{2}$ with the highest bandgap $(3.12 \mathrm{eV})$ was achieved with $1 \%$ of Mn dopant content calcined at $500{ }^{\circ} \mathrm{C}$.
\end{abstract}

Keywords: $\mathrm{Mn}$-doped $\mathrm{TiO}_{2}-\mathrm{ZrO}_{2}$; bandgap; manganese; $\mathrm{ZrO}_{2} ; \mathrm{TiO}_{2}$

\section{- INTRODUCTION}

Titanium dioxide $\left(\mathrm{TiO}_{2}\right)$ is a semiconductor that has been widely used as a photocatalyst material because of its interesting properties such as low cost, strong oxidizing power, non-toxicity, and chemical inertness [1]. Another photocatalyst material that has attracted attention is zirconium oxide $\left(\mathrm{ZrO}_{2}\right)$ which has good stability and easily produces holes in the valence band, leading to strong interactions with the active component. $\mathrm{ZrO}_{2}$ is resistant to both alkali and acid conditions as well as oxidation and reduction reactions. Moreover, because of its properties, composites containing $\mathrm{ZrO}_{2}$ as the main material have pulled much attention in recent years. This is mainly because of the difference in energy levels between $\mathrm{ZrO}_{2}$ and other semiconductors to efficiently separate the charges, thus decrease the recombination of electrons and holes [2-3].
Previous research reported that coupling $\mathrm{ZrO}_{2}$ with $\mathrm{TiO}_{2}$ at Ti:Zr molar ratio of $1: 1$ had resulted in zirconium titanate hollow sphere with a non-visiblelight response $(3.31 \mathrm{eV})$, however, this material has a higher redox potential [1]. Pirzada et al. [2] successfully synthesized nanocomposite $\mathrm{TiO}_{2} / \mathrm{ZrO}_{2}$ with the lowest bandgap (3.26 eV, non-visible light response) with an average particle diameter particle of $10.5 \mathrm{~nm}$ yielding a higher redox capability. However, the photocatalytic performance of semiconductor can be improved with an approach to broaden the photo-response by doping with various metals [3]. Doping of semiconductor material with transition metals leads to reduction of bandgap and it will provide a good photocatalytic activity [4].

The metallic dopants with $3 \mathrm{~d}$ orbitals, such as Mn, $\mathrm{Fe}, \mathrm{Co}$ and $\mathrm{Zn}$, had been studied and reported in recent years [5-9]. Transition metal will reduce the particle size 
of photocatalyst and increase its surface area, Table 1 shows the use of dopants with $3 \mathrm{~d}$ orbitals on the photocatalyst materials that had been studied previously. Doping photocatalyst with transition metals increases the surface defects and optical absorption of light, which can ultimately lead to an increase in the efficiency of the photocatalyst [9]. The lowest bandgap of $\mathrm{TiO}_{2}-\mathrm{ZrO}_{2}$ doped using Fe $(2.83 \mathrm{eV})$, Co $(2.94 \mathrm{eV})$ and $\mathrm{Zn}(2.87 \mathrm{eV})$ were achieved in composites with $7 \%$ of iron content calcined at $500{ }^{\circ} \mathrm{C}, 3 \%$ of cobalt content calcined at $500{ }^{\circ} \mathrm{C}$, and $5 \%$ of zinc content calcined at $900{ }^{\circ} \mathrm{C}$, respectively [6-8]. The properties of semiconductor are enhanced after manganese doping because $\mathrm{Mn}^{2+}$ and $\mathrm{Mn}^{3+}$ exist on the surface of photocatalyst and catch the electron in semiconductor. Therefore, $\mathrm{Mn}$ should trap electrons and suppress electron-hole recombination. Thus, the lower the electron-hole recombination is, the higher the quantum efficiency of the photons will be and then will reduce bandgap value [10]. Mragui et al. [5] successfully synthesized $\mathrm{Mn}-\mathrm{TiO}_{2}$ with $10 \%$ of $\mathrm{Mn}$ content and bandgap of $2.95 \mathrm{eV}$, using $\mathrm{MnCl}_{2} \cdot 4 \mathrm{H}_{2} \mathrm{O}$ as a dopant source.

Beside the addition of dopant, the calcination temperature can also affect the bandgap value of the photocatalyst material by changing the structure of the material. $\mathrm{TiO}_{2}$ which has been synthesized at high calcination $\left(400{ }^{\circ} \mathrm{C}\right)$ could have higher photoactivity compared to the $\mathrm{TiO}_{2}$ which was synthesized at low temperature $\left(200{ }^{\circ} \mathrm{C}\right)$ [11]. However, photocatalytic activity is related to the combination properties of crystalline phase, particle size, surface area, electron-hole recombinant, bandgap energy, pore volume, and surface chemical state [11-12].

This study was conducted with various Mn dopant contents and calcination temperatures to determine its effects on the properties of $\mathrm{Mn}$-doped $\mathrm{TiO}_{2}-\mathrm{ZrO}_{2}$ composite. The addition of $\mathrm{Mn}$ dopant and increased

Table 1. Bandgap data of $\mathrm{Mn}-\mathrm{TiO}_{2}, \mathrm{Fe}, \mathrm{Co}$ and $\mathrm{Zn}$ doped $\mathrm{TiO}_{2}-\mathrm{ZrO}_{2}$ at the optimum condition

\begin{tabular}{ll}
\hline \multicolumn{1}{c}{ Sample } & $\mathrm{Eg}(\mathrm{eV})$ \\
\hline $\mathrm{Mn}-\mathrm{TiO}_{2} 10 \% 500{ }^{\circ} \mathrm{C}$ & $2.95[5]$ \\
$\mathrm{Co}-\mathrm{ZrO}_{2}-\mathrm{TiO}_{2} 3 \% 500{ }^{\circ} \mathrm{C}$ & $2.94[6]$ \\
$\mathrm{Fe}-\mathrm{ZrO}_{2}-\mathrm{TiO}_{2} 7 \% 500{ }^{\circ} \mathrm{C}$ & $2.83[7]$ \\
$\mathrm{Zn}-\mathrm{ZrO}_{2}-\mathrm{TiO}_{2} 5900^{\circ} \mathrm{C}$ & $2.87[8]$ \\
\hline
\end{tabular}

calcination temperature were expected to produce a $\mathrm{TiO}_{2}-\mathrm{ZrO}_{2}$ composite with reduced bandgap energy. $\mathrm{Mn}$-doped $\mathrm{TiO}_{2}$ was developed on the surface of $\mathrm{ZrO}_{2}$ by the sol-gel process. The sol-gel method was chosen because it has several advantages, such as an easy process, simple equipment, homogeneous phase, the ability to control the crystal size, and low temperature condition [13-14].

\section{- EXPERIMENTAL SECTION}

\section{Materials}

Titanium(IV) isopropoxide (TTIP, 97\%, SigmaAldrich) was used as $\mathrm{TiO}_{2}$ precursor. Manganese(II) chloride tetrahydrate $\left(\mathrm{MnCl}_{2} \cdot 4 \mathrm{H}_{2} \mathrm{O}, 98 \%\right.$, Merck $)$ was used as source of $\mathrm{Mn}$ dopant. Zirconia powder $\left(\mathrm{ZrO}_{2}\right.$, Jiaozuo Huasu) was used as the source of coupling semiconductor. Absolute ethanol (Merck) and demineralized water (Jaya Sentosa) were used as solvents.

\section{Instrumentation}

Specular reflectance UV-Vis spectrophotometer (SR UV-Vis) UV1700 Pharmaspec was used to measure the ultraviolet and visible (UV-Vis) absorption of the material. Fourier-transform infrared spectroscopy (FTIR) analysis was conducted using Thermo Nicolet iS10. The crystal structures of material were analyzed by using X-ray powder diffractometer (XRD) PANalytical X'Pert PRO MRD instrument with $\mathrm{Cu}$ Ka radiation. Surface morphology was observed with scanning electron microscopy equipped with energy dispersive Xray spectrometer (SEM-EDX) Phenom Desktop ProXL.

\section{Procedure}

Mn-doped $\mathrm{TiO}_{2}-\mathrm{ZrO}_{2}$ was synthesized by the solgel method. Firstly, $2.5 \mathrm{~mL}$ of TTIP was dissolved in 25 $\mathrm{mL}$ of absolute ethanol and then stirred homogeneously. One gram of $\mathrm{ZrO}_{2}$ powder was dispersed into $25 \mathrm{~mL}$ of demineralized water then as much as $14.38,43.59,72.66$, 101.72 , and $130.79 \mathrm{mg}$ of $\mathrm{MnCl}_{2} \cdot 4 \mathrm{H}_{2} \mathrm{O}$ was separately added dropwise into the mixture to obtain 1, 3, 5, 7 and 9\% Mn wt./Ti wt., respectively. The mixture was stirred for $30 \mathrm{~min}$ and separated by centrifugation at $2000 \mathrm{rpm}$ for $1 \mathrm{~h}$. The obtained solid was aged in the open space 
for $24 \mathrm{~h}$ and then heated at $60^{\circ} \mathrm{C}$ for $24 \mathrm{~h}$. Composites with various $\mathrm{Mn}$ dopant contents were calcined at $500{ }^{\circ} \mathrm{C}$ for $4 \mathrm{~h}$ to observe the effect of $\mathrm{Mn}$ contents. Additionally, the composite with $5 \%$ of $\mathrm{Mn}$ content was calcined at 700 and $900{ }^{\circ} \mathrm{C}$ to observe the effect of calcination temperature. The variation of dopant percentage and calcination temperature were based on the previous works [6-8]. All samples were characterized by using XRD, FTIR, SR UV-Vis and SEM-EDX.

\section{- RESULTS AND DISCUSSION}

Fig. 1 displays the morphology and its corresponding EDX spectra of $5 \% \mathrm{Mn}$-doped $\mathrm{TiO}_{2}-\mathrm{ZrO}_{2}$ calcined at $500{ }^{\circ} \mathrm{C}$. The morphology of $\mathrm{Mn}$-doped $\mathrm{TiO}_{2}$ $\mathrm{ZrO}_{2}$ appears to be rough and its particles appear to be agglomerated with an estimated diameter of 1-5 $\mu \mathrm{m}$.
Table 2 shows the result of EDX spectra analysis. EDX analysis confirms that $\mathrm{TiO}_{2}-\mathrm{ZrO}_{2}$ was successfully synthesized and $0.33 \%$ of $\mathrm{Mn}$ was present in the composite.

FTIR spectra of $\mathrm{Mn}$-doped $\mathrm{TiO}_{2}-\mathrm{ZrO}_{2}$ with various contents of $\mathrm{Mn}$ dopant and calcination temperatures are shown together in Fig. 2. FTIR spectra show hydroxyl stretching vibration of $\mathrm{H}_{2} \mathrm{O}$ around $3300-3700 \mathrm{~cm}^{-1}$ and hydroxyl bending vibration of $\mathrm{H}_{2} \mathrm{O}$ around $1650 \mathrm{~cm}^{-1}$ [15]. The $\mathrm{Zr}-\mathrm{O}$ vibration was found around 420 and $744 \mathrm{~cm}^{-1}$ correspond to monoclinic structure of $\mathrm{ZrO}_{2}$ [3]. At low wavenumber region, the absorption belonged to the vibration of Ti-O-Ti, Mn-O-Ti and $\mathrm{Mn}-\mathrm{O}$ are found around 400-700 $\mathrm{cm}^{-1}$ [16]. Spectra of $\mathrm{Mn}$-doped $\mathrm{TiO}_{2-}$ $\mathrm{ZrO}_{2}$ has combined characteristic vibrations between $\mathrm{TiO}_{2}$ and $\mathrm{ZrO}_{2}$, where there are broad stretching vibration

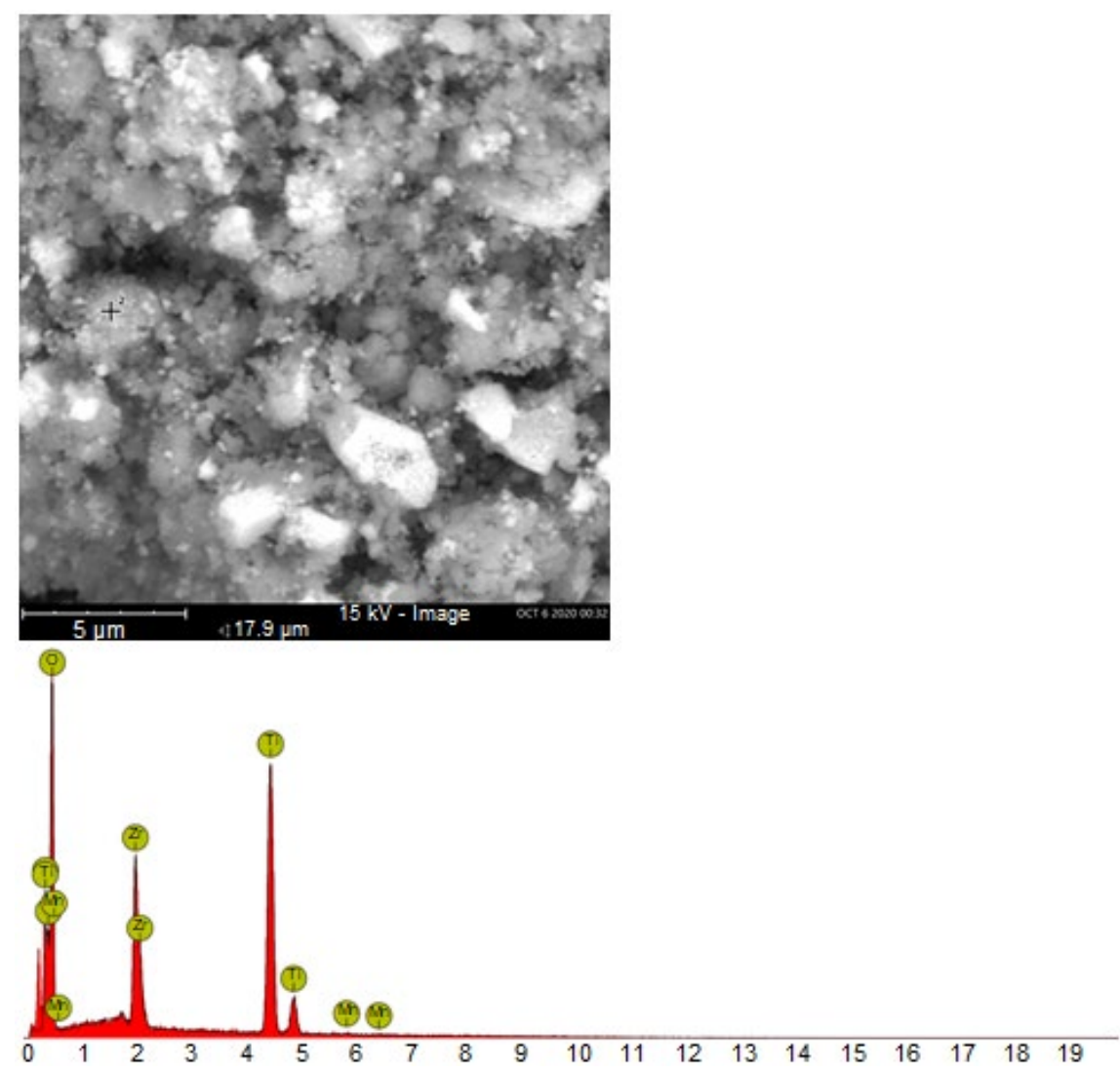

Fig 1. SEM image of $\mathrm{TiO}_{2}-\mathrm{ZrO}_{2}$ with $5 \% \mathrm{Mn}$ content calcined at $500{ }^{\circ} \mathrm{C}$ and its corresponding EDX spectra

Table 2. EDX analysis of $5 \% \mathrm{Mn}$-doped $\mathrm{TiO}_{2}-\mathrm{ZrO}_{2}$ calcined at $500{ }^{\circ} \mathrm{C}$

\begin{tabular}{|c|c|c|c|c|c|}
\hline \multirow{2}{*}{ Sample } & \multicolumn{5}{|c|}{ \% Weight } \\
\hline & $\mathrm{Zr}$ & $\mathrm{Ti}$ & $\mathrm{O}$ & $\mathrm{Mn}$ & Total \\
\hline $5 \% \mathrm{Mn}$-doped $\mathrm{TiO}_{2}-\mathrm{ZrO}_{2} @ 500^{\circ} \mathrm{C}$ & 49.09 & 32.42 & 18.16 & 0.33 & 100 \\
\hline
\end{tabular}




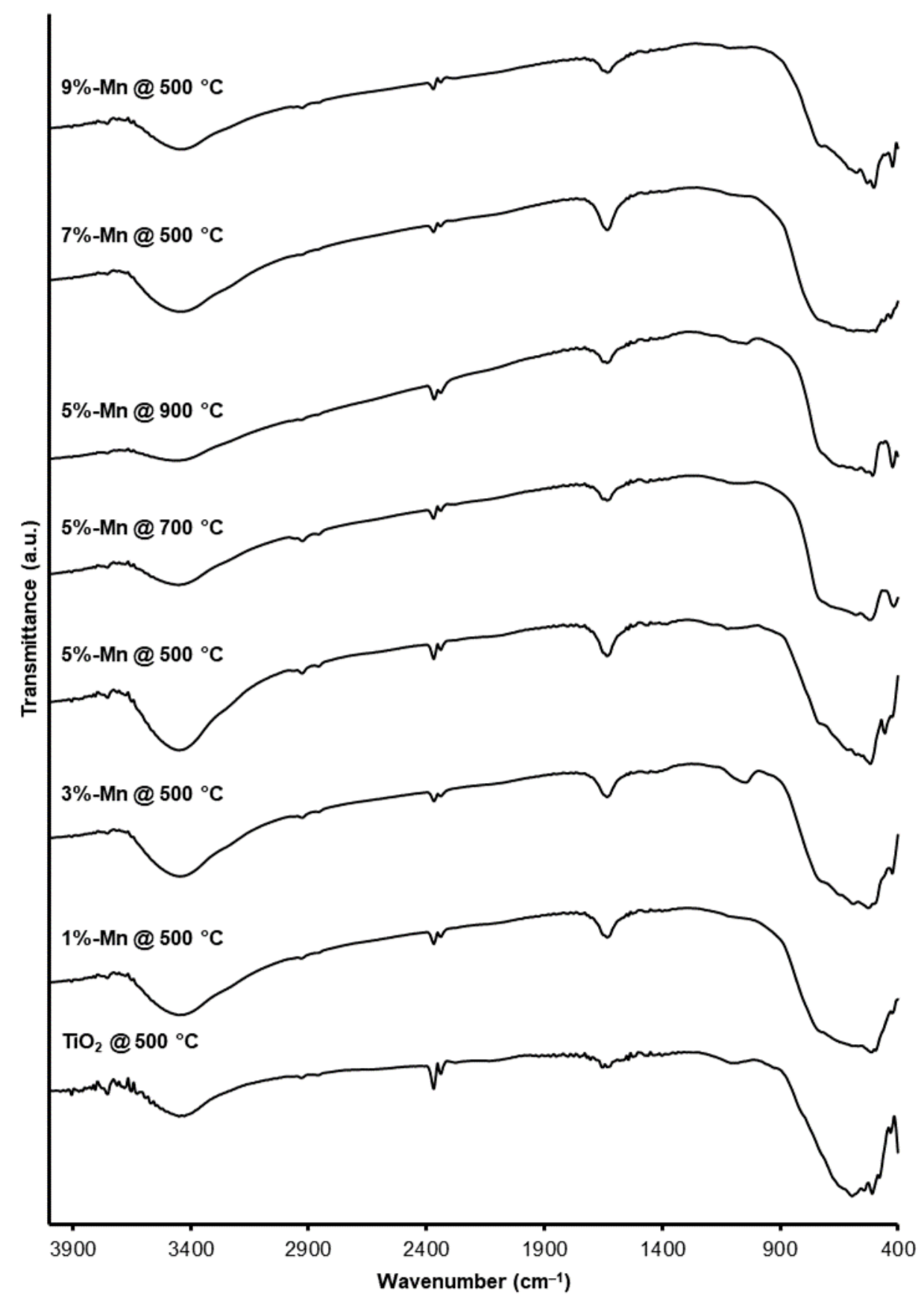

Fig 2. FTIR spectra of $\mathrm{Mn}$-doped $\mathrm{TiO}_{2}-\mathrm{ZrO}_{2}$ with various dopant contents and calcination temperatures

of $\mathrm{OH}$ at $3300-3700 \mathrm{~cm}^{-1}$ and also around $400-700 \mathrm{~cm}^{-1}$, which is probably the vibration of $\mathrm{Zr}-\mathrm{O}-\mathrm{Zr}$, Ti-O-Ti, or $\mathrm{Mn}-\mathrm{O}-\mathrm{Ti}$. The stretching and bending intensities of $\mathrm{H}_{2} \mathrm{O}$ decrease at $9 \%$ of $\mathrm{Mn}$-doped $\mathrm{TiO}_{2}-\mathrm{ZrO}_{2}$, possibly because the number of $\mathrm{Mn}$ replacing Ti increases. The hydroxyl bending and stretching intensities of $\mathrm{H}_{2} \mathrm{O}$ at 1630 and $3300-3700 \mathrm{~cm}^{-1}$, respectively, decrease with the increase of calcination temperature. This possibly happened because $\mathrm{H}_{2} \mathrm{O}$ molecules of synthesized material are released due to the high temperature heating during the calcination process.

Fig. 3 shows diffraction patterns of various $\mathrm{Mn}$ doped $\mathrm{TiO}_{2}-\mathrm{ZrO}_{2}$ composites, while Table 3 presents their calculated crystallite sizes based on Scherrer's equation [17]. The diffraction patterns confirm the presence of monoclinic $\mathrm{ZrO}_{2}$ and anatase $\mathrm{TiO}_{2}$. There are 


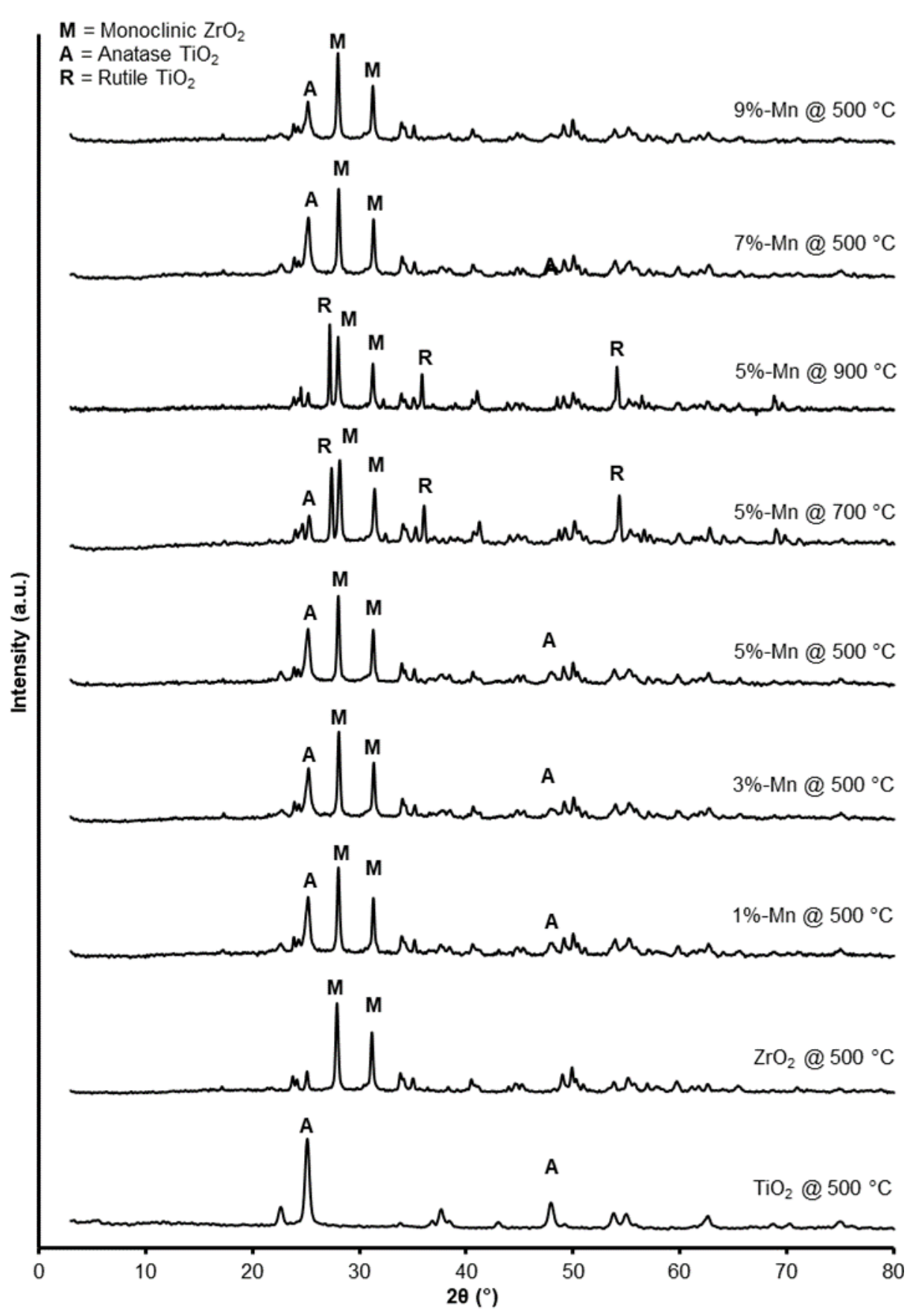

Fig 3. Diffraction patterns of $\mathrm{Mn}$-doped $\mathrm{TiO}_{2}-\mathrm{ZrO}_{2}$ with various dopant contents and calcination temperatures

no tetragonal and rutile patterns observed at $500{ }^{\circ} \mathrm{C}$. Monoclinic peaks are observed at $28.21^{\circ}(-111)$ and $31.50^{\circ}$ (111), according to ICDD:01-083-0944, while anatase peaks are observed at $25.28^{\circ}$ (101) and $48.05^{\circ}$ (200), according to ICDD:00-021-1272. All Mn-doped $\mathrm{TiO}_{2^{-}}$ $\mathrm{ZrO}_{2}$ had a pattern combination of high monoclinic and anatase intensities at $500{ }^{\circ} \mathrm{C}$, while no $\mathrm{Mn}$ pattern was observed. The high intensity of monoclinic peaks shows that $\mathrm{ZrO}_{2}$ has a greater amount than anatase. The average crystallite sizes of monoclinic and anatase remain unchanged significantly as the content of manganese dopant increases. It indicates that $\mathrm{Mn}^{2+}(67$ pm) has substituted $\mathrm{Ti}^{4+}(60.5 \mathrm{pm})$ in the anatase $\mathrm{TiO}_{2}$ structure, as the ionic radius of both metal ions are similar [18]. Some literature reported that $\mathrm{TiO}_{2}$ starts to form rutile structure at $500^{\circ} \mathrm{C}[7,11]$. One report found 
Table 3. Average crystallite size of various $\mathrm{Mn}$-doped $\mathrm{TiO}_{2}-\mathrm{ZrO}_{2}$

\begin{tabular}{llcc}
\hline \multicolumn{1}{c}{ Sample } & Crystal phase & $(\mathrm{hkl})$ & $\mathrm{L}(\mathrm{nm})$ \\
\hline $\mathrm{ZrO}_{2} @ 500^{\circ} \mathrm{C}$ & Monoclinic & $(-111)$ & 26.36 \\
$\mathrm{TiO}_{2} @ 500^{\circ} \mathrm{C}$ & Anatase & $(101)$ & 15.72 \\
& Monoclinic & $(-111)$ & 25.10 \\
$1 \%-\mathrm{Mn} @ 500^{\circ} \mathrm{C}$ & Anatase & $(101)$ & 15.00 \\
& Monoclinic & $(-111)$ & 27.94 \\
$3 \%-\mathrm{Mn} @ 500^{\circ} \mathrm{C}$ & Anatase & $(101)$ & 14.96 \\
& Monoclinic & $(-111)$ & 28.82 \\
$5 \%-\mathrm{Mn} @ 500^{\circ} \mathrm{C}$ & Anatase & $(101)$ & 15.60 \\
& Monoclinic & $(-111)$ & 22.88 \\
& Anatase & $(101)$ & 18.44 \\
$5 \%-\mathrm{Mn} @ 700^{\circ} \mathrm{C}$ & Rutile & $(110)$ & 29.19 \\
& Monoclinic & $(-111)$ & 30.62 \\
$5 \%-\mathrm{Mn} @ 900^{\circ} \mathrm{C}$ & Rutile & $(110)$ & 44.64 \\
& Monoclinic & $(-111)$ & 28.28 \\
$7 \%-\mathrm{Mn} @ 500{ }^{\circ} \mathrm{C}$ & Anatase & $(101)$ & 15.72 \\
& Monoclinic & $(-111)$ & 29.01 \\
$9 \%-\mathrm{Mn} @ 500^{\circ} \mathrm{C}$ & Anatase & $(101)$ & 15.12 \\
\hline
\end{tabular}

that the presence of $\mathrm{Mn}^{2+}$ ion promotes anatase-rutile phase transformation [16], while another report suggested that $\mathrm{Zr}^{4+}$ prevents phase transformation of anatase [19]. The presence of $\mathrm{ZrO}_{2}$ is assumed to be responsible for preventing the anatase-to-rutile transformation on $\mathrm{Mn}$ doped $\mathrm{TiO}_{2}-\mathrm{ZrO}_{2}$ calcined at $500{ }^{\circ} \mathrm{C}$.

The diffraction patterns also confirm the presence of $\mathrm{ZrO}_{2}$ monoclinic, $\mathrm{TiO}_{2}$ anatase and $\mathrm{TiO}_{2}$ rutile at $5 \% \mathrm{Mn}$ doped $\mathrm{TiO}_{2}-\mathrm{ZrO}_{2}$ calcined at 700 and $900{ }^{\circ} \mathrm{C}$. Monoclinic and anatase peaks were observed similar to the previous discussion, but the intensity of anatase decreased while the rutile increased. Rutile peaks are observed at $27.91^{\circ}$ (110), $36.43^{\circ}(101)$ and $55.11^{\circ}$ (211), according to ICDD:01-088-1175 [20]. The intensity of anatase decreased as the calcination temperature increased because of the anatase-to-rutile transformation. The rutile pattern starts to be observed at $700{ }^{\circ} \mathrm{C}$ and almost all anatase peaks transform into rutile at $900{ }^{\circ} \mathrm{C}$. The average crystallite size of monoclinic $\mathrm{ZrO}_{2}$ also remains unchanged at higher calcination temperature. On the other hand, there is an increase in rutile crystallite size, which is possibly due to agglomeration of the rutile phase at $900{ }^{\circ} \mathrm{C}$.

The SR UV-Vis absorption spectra of the Mn-doped $\mathrm{TiO}_{2}-\mathrm{ZrO}_{2}$ are shown in Fig. 4 with the variation of $\mathrm{Mn}$ dopant content and calcination temperature, while Table 4 presents the bandgap energy values. The bandgap energy of the composites was evaluated by using absorption edge cross method. All synthesized materials have lower $\mathrm{E}_{\mathrm{g}}$ values than $\mathrm{TiO}_{2}(3.12 \mathrm{eV})$ and $\mathrm{ZrO}_{2}(3.23 \mathrm{eV})[8,21]$. The SR UV-Vis spectra show that all synthesized materials have absorption edge at visible range (above $400 \mathrm{~nm}$ ). The presence of $\mathrm{Mn}^{2+}$ ions forms a new energy orbital under the conduction band and decreases the $\mathrm{E}_{\mathrm{g}}$ value of the materials [22]. The increased calcination temperature reduces the $\mathrm{E}_{\mathrm{g}}$ values of $\mathrm{Mn}$ doped $\mathrm{TiO}_{2}-\mathrm{ZrO}_{2}$. This is possibly because the higher calcination temperature would facilitate the phase transformation of anatase to rutile and decrease the $\mathrm{E}_{\mathrm{g}}$ value [23].

Based on the obtained results, the synthesized Mndoped $\mathrm{TiO}_{2}-\mathrm{ZrO}_{2}$ using the sol-gel method had been successfully carried out. The Mn dopant was proven to reduce the $\mathrm{E}_{\mathrm{g}}$ values from 3.12 to $2.78 \mathrm{eV}$ with an optimum content of $5 \%$ and calcination temperature of $900^{\circ} \mathrm{C}$. The addition of Mn dopant $1-7 \%$ was shown to be able to reduce the $\mathrm{E}_{\mathrm{g}}$ value, and it may possibly increase the response of the synthesized material under visible-light range. The $\mathrm{E}_{\mathrm{g}}$ values of $\mathrm{Mn}$-doped $\mathrm{TiO}_{2}-\mathrm{ZrO}_{2}$ increased as the addition of $\mathrm{Mn}$ dopant reached above $7 \%$ 


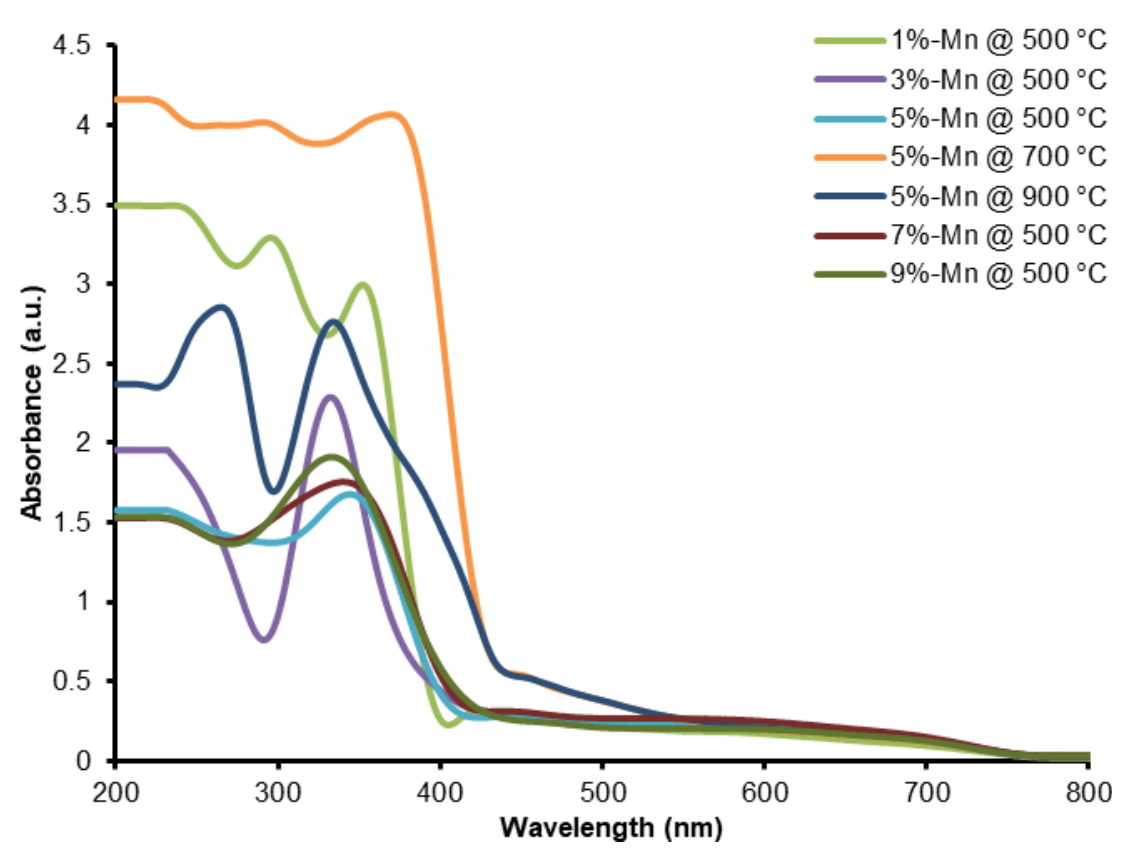

Fig 4. SR UV-Vis absorption spectra of various $\mathrm{Mn}$-doped $\mathrm{TiO}_{2}-\mathrm{ZrO}_{2}$

Table 4. Bandgap energy data of $\mathrm{Mn}$-doped $\mathrm{TiO}_{2}-\mathrm{ZrO}_{2}$

\begin{tabular}{cc}
\hline Sample & $\mathrm{Eg}(\mathrm{eV})$ \\
\hline $1 \%-\mathrm{Mn} @ 500^{\circ} \mathrm{C}$ & 3.12 \\
$3 \%-\mathrm{Mn} @ 500{ }^{\circ} \mathrm{C}$ & 3.09 \\
$5 \%-\mathrm{Mn} @ 500^{\circ} \mathrm{C}$ & 3.03 \\
$5 \%-\mathrm{Mn} @ 700^{\circ} \mathrm{C}$ & 2.87 \\
$5 \%-\mathrm{Mn} @ 900^{\circ} \mathrm{C}$ & 2.78 \\
$7 \%-\mathrm{Mn} @ 500^{\circ} \mathrm{C}$ & 2.81 \\
$9 \%-\mathrm{Mn} @ 500^{\circ} \mathrm{C}$ & 2.95 \\
\hline
\end{tabular}

due to the heterojunction effect appearing and cancelling the dopant effect [4,6,21]. Furthermore, the higher calcination temperature was proven to enable the material transformations phase of anatase to rutile, which causes the $E_{g}$ value to be smaller. This result corresponds with other previous works in which the addition of dopant between $1-9 \%$ and calcination temperature would show optimum condition of doped composite [4,6-8].

\section{- CONCLUSION}

The investigation of $\mathrm{Mn}$ dopant content and calcination temperature affecting the properties of $\mathrm{Mn}$ doped $\mathrm{TiO}_{2}-\mathrm{ZrO}_{2}$ composite had been successfully conducted. The results of EDX analysis confirm the presence of $\mathrm{Zr}, \mathrm{Ti}, \mathrm{O}$ and $\mathrm{Mn}$. It was confirmed by the $\mathrm{XRD}$ analysis that the presence of $\mathrm{Zr}^{4+}$ inhibits the anatase-to-rutile transformation at higher calcination temperature. The bandgap of $\mathrm{Mn}$-doped $\mathrm{TiO}_{2}-\mathrm{ZrO}_{2}$ decreases as the calcination temperature and the dopant content increase until reaching the optimum condition. The composite with the lowest bandgap is Mn-doped $\mathrm{TiO}_{2}-\mathrm{ZrO}_{2}$ with $5 \%$ of $\mathrm{Mn}$ content calcined at $900^{\circ} \mathrm{C}$. All of the synthesized composites in this research can be considered as a potential visible-light-responsive photocatalyst.

\section{- ACKNOWLEDGMENTS}

We would like to express our gratitude to The Ministry of Research, Technology and Higher Education of the Republic of Indonesia for their support on this work through PDUPT 2020 Grant (2828/UN1.DITLIT/DIT-LIT/PT/2020).

\section{- REFERENCES}

[1] Syoufian, A., Manako, Y., and Nakashima, K., 2015, Sol-gel preparation of photoactive srilankite-type zirconium titanate hollow spheres by templating sulfonated polystyrene latex particles, Powder Technol., 280, 207-210.

[2] Pirzada, B.M., Mir, N.A., Qutub, N., Mehraj, O., Sabir, S., and Muneer, M., 2015, Synthesis, 
characterization and optimization of photocatalytic activity of $\mathrm{TiO}_{2} / \mathrm{ZrO}_{2}$ nanocomposite heterostructures, Mater. Sci. Eng., B, 193, 137-145.

[3] Cheng, Q., Yang, W., Chen, Q., Zhu, J., Li, D., Fu, L., and Zhou, L., 2020, Fe-doped zirconia nanoparticles with highly negative conduction band potential for enhancing visible light photocatalytic performance, Appl. Surf. Sci., 530, 147291.

[4] Deng, Q.R., Xia, X.H., Guo, M.L., Gao, Y., and Shao, G., 2011, Mn-doped $\mathrm{TiO}_{2}$ nanopowders with remarkable visible light photocatalytic activity, Mater. Lett., 65 (13), 2051-2054.

[5] El Mragui, A., Zegaoui, O., and Daou, I., 2019, Synthesis, characterization and photocatalytic properties under visible light of doped and co-doped $\mathrm{TiO}_{2}$-based nanoparticles, Mater. Today: Proc., 13, 857-865.

[6] Sulaikhah, E.F., Kurniawan, R., Pradipta, M.F., Trisunaryanti, W., and Syoufian, A., 2020, Cobalt doping on zirconium titanate as a potential photocatalyst with visible-light-response, Indones. J. Chem., 20 (4), 911-918.

[7] Kurniawan, R., Sudiono, S., Trisunaryanti, W., and Syoufian, A., 2019, Synthesis of iron-doped zirconium titanate as a potential visible-light responsive photocatalyst, Indones. J. Chem., 19 (2), 454-460.

[8] Alifi, A., Kurniawan, R., and Syofian, A., 2020, Zincdoped titania embedded on the surface of zirconia: A potential visible-responsive photocatalyst material, Indones. J. Chem., 20 (6), 1374-1381.

[9] Singh, J., Rathi, A., Rawat, M., Kumar, V., and Kim, K.H., 2019, The effect of manganese doping on structural, optical, and photocatalytic activity of zinc oxide nanoparticles, Composites, Part B, 166, 361-370.

[10] Xu, Y., Lei, B., Guo, L., Zhou, W., and Liu, Y., 2008, Preparation, characterization and photocatalytic activity of manganese doped $\mathrm{TiO}_{2}$ immobilized on silica gel, J. Hazard. Mater., 160 (1), 78-82.

[11] Wu, H., Ma, J., Zhang, C., and He, H., 2014, Effect of $\mathrm{TiO}_{2}$ calcination temperature on the photocatalytic oxidation of gaseous $\mathrm{NH}_{3}$, J. Environ. Sci., 26 (3), 673-682.
[12] Lv, K., Xiang, Q., and Yu, J., 2011, Effect of calcination temperature on morphology and photocatalytic activity of anatase $\mathrm{TiO}_{2}$ nanosheets with exposed \{001\} facets, Appl. Catal., B, 104 (3-4), 275-281.

[13] Tomar, L.J., Bhatt, P.J., Desai, R.k., and Chakrabarty, B.S., 2014, Effect of preparation method on optical and structural properties of $\mathrm{TiO}_{2} / \mathrm{ZrO}_{2}$ nanocomposite, J. Nanotechnol. Adv. Mater., 2 (1), 27-33.

[14] Wellia, D.V., Xu, Q.C., Sk, M.A., Lim, K.H., Lim, T.M., and Tan, T.T.Y., 2011, Experimental and theoretical studies of Fe-doped $\mathrm{TiO}_{2}$ films prepared by peroxo sol-gel method, Appl. Catal., A, 401 (12), 98-105.

[15] Sudrajat, H., Babel, S., Ta, A. T., and Nguyen, T. K., 2020, Mn-doped $\mathrm{TiO}_{2}$ photocatalysts: Role, chemical identity, and local structure of dopant, $J$. Phys. Chem. Solids, 144, 109517.

[16] Sharotri, N., Sharma, D., and Sud, D., 2019, Experimental and theoretical investigations of $\mathrm{Mn}$ $\mathrm{N}$-co-doped $\mathrm{TiO}_{2}$ photocatalyst for visible light induced degradation of organic pollutants, J. Mater. Res. Technol., 8 (5), 3995-4009.

[17] Fischer, K., Schulz, P., Atanasov, I., Abdul Latif, A., Thomas, I., Kühnert, M., Prager, A., Griebel, J., and Schulze, A., 2018, Synthesis of high crystalline $\mathrm{TiO}_{2}$ nanoparticles on a polymer membrane to degrade pollutants from water, Catalysts, 8 (9), 376.

[18] Gao, X., Zhou, B., and Yuan, R., 2015, Doping a metal (Ag, $\mathrm{Al}, \mathrm{Mn}, \mathrm{Ni}$ and $\mathrm{Zn}$ ) on $\mathrm{TiO}_{2}$ nanotubes and its effect on Rhodamine $\mathrm{B}$ photocatalytic oxidation, Environ. Eng. Res., 20 (4), 329-335.

[19] Venkatachalam, N., Palanichamy, M., Arabindoo, B., and Murugesan, V., 2007, Enhanced photocatalytic degradation of 4-chlorophenol by $\mathrm{Zr}^{4+}$ doped nano $\mathrm{TiO}_{2}$, J. Mol. Catal. A: Chem., 266 (1-2), 158-165.

[20] Radić, N., Grbić, B., Petrović, S., Stojadinović, S., Tadić, N., and Stefanov, P., 2020, Effect of cerium oxide doping on the photocatalytic properties of rutile $\mathrm{TiO}_{2}$ films prepared by spray pyrolysis, 
Physica B, 599, 412544.

[21] Andita, K.R., Kurniawan, R., and Syoufian, A., 2019, Synthesis and characterization of $\mathrm{Cu}$-doped zirconium titanate as a potential visible-light responsive photocatalyst, Indones. J. Chem., 19 (3), 761-766.

[22] Abdelouahab Reddam, H., Elmail, R., Lloria, S.C., Monrós Tomás, G., Reddam, Z.A., and Coloma-
Pascual, F., 2020, Synthesis of Fe, $\mathrm{Mn}$ and $\mathrm{Cu}$ modified $\mathrm{TiO}_{2}$ photocatalysts for photodegradation of Orange II, Bol. Soc. Esp. Ceram. Vidrio, 59 (4), 138-148.

[23] Samet, L., Ben Nasseur, J., Chtourou, R., March, K., and Stephan, O., 2013, Heat treatment effect on the physical properties of cobalt doped $\mathrm{TiO}_{2}$ sol-gel materials, Mater. Charact., 85, 1-12. 